\title{
Methods and Devices for Forming Rehabilitation Processes. Application of Artificial Intelligence and Artificial Neural Networks for Rehabilitation
}

\author{
Alexey Imamov
}

\begin{abstract}
In a modern society that implements and organizes various options for comprehensive and versatile development of the innovative economy, especially in areas related to smart industries and technologies, stress loads of all types that arise from the most active organizers of project development processes and generators of new technical and commercial ideas aimed at optimizing and accelerating development processes require an adequate response and unobtrusive, but extremely reliable and natural technologies and special equipment for rehabilitation. Keywords: rehabilitation, artificial intelligence, neural networks, stress

В современном обществе, реализующем и организовывающем различные варианты комплексного разностороннего развития инновационной экономики, особенно в областях связанных с умными производствами и технологиями, стрессовые нагрузки всех видов, возникающие у наиболее активных организаторов процессов развития проектов и генераторов новых технических и коммерческих идей, направленных на оптимизацию и акселерацию процессов развития, требуют адекватной реакции и ненавязчивых, но предельно надёжных и естественных технологий и специального оборудования для реабилитации. Настольные спортивные игры - один из важнейших и перспективных источников для всесторонних технологий реабилитации.

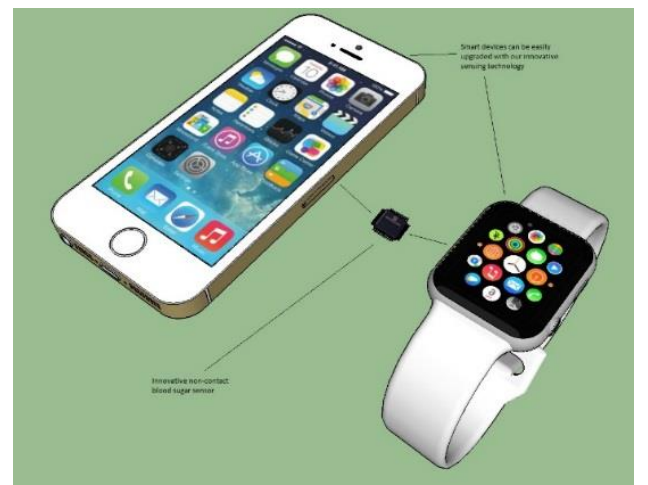

Рисунок 1, - на рисунке показана модель системных управляющих и регламентирующих комплексных модельных подсистем с использованием в качестве динамичных связей между подвижным контролируемым объектом и средствами мобильной связи бесконтактных резонансных сенсоров, работающих по принципам электромагнитной резонансной спектроскопии и имеющих различное конструктивное исполнение.
\end{abstract}

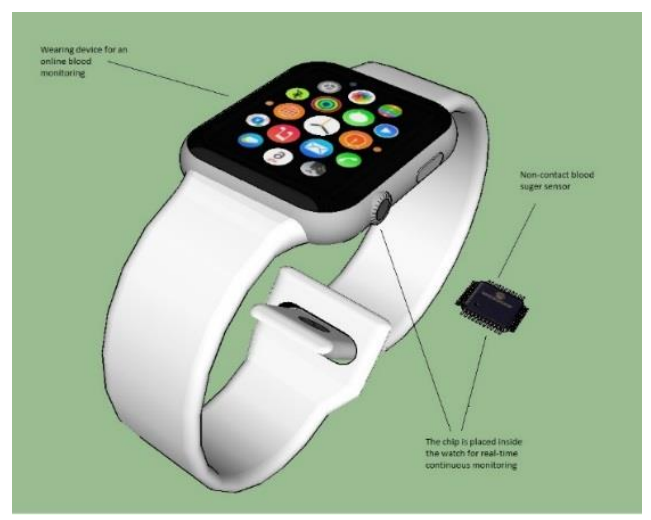

Рисунок 2 , - на рисунке также показана модель системных управляющих и регламентирующих комплексных модельных подсистем с использованием в качестве динамичных связей между подвижным контролируемым объектом и средствами мобильной связи выполненными в виде умных часов, бесконтактных резонансных сенсоров, работающих по принципам электромагнитной резонансной спектроскопии и имеющих различное конструктивное исполнение. 
Для так называемых умных часов исполнение сенсора представляет собой плоскую катушку - электронную микроплату с оригинальной топологией плоского соленоида. Такой сенсор получает энергию от батареи часов и находится постоянно в режиме контроля параметров организма игрока в настольный теннис.

При этом в мониторинге в режиме реального времени могут измеряться несколько важных параметров на которые может оказывать влияние чересчур интенсивный характер игры. Например, концентрация сахара в крови, кровяное давление и т.п.

Особую важность приобретают эти варианты применения в случае интеграции в программные системы всего реабилитационного комплекса элементов искусственного интеллекта и искусственных нейронных сетей.

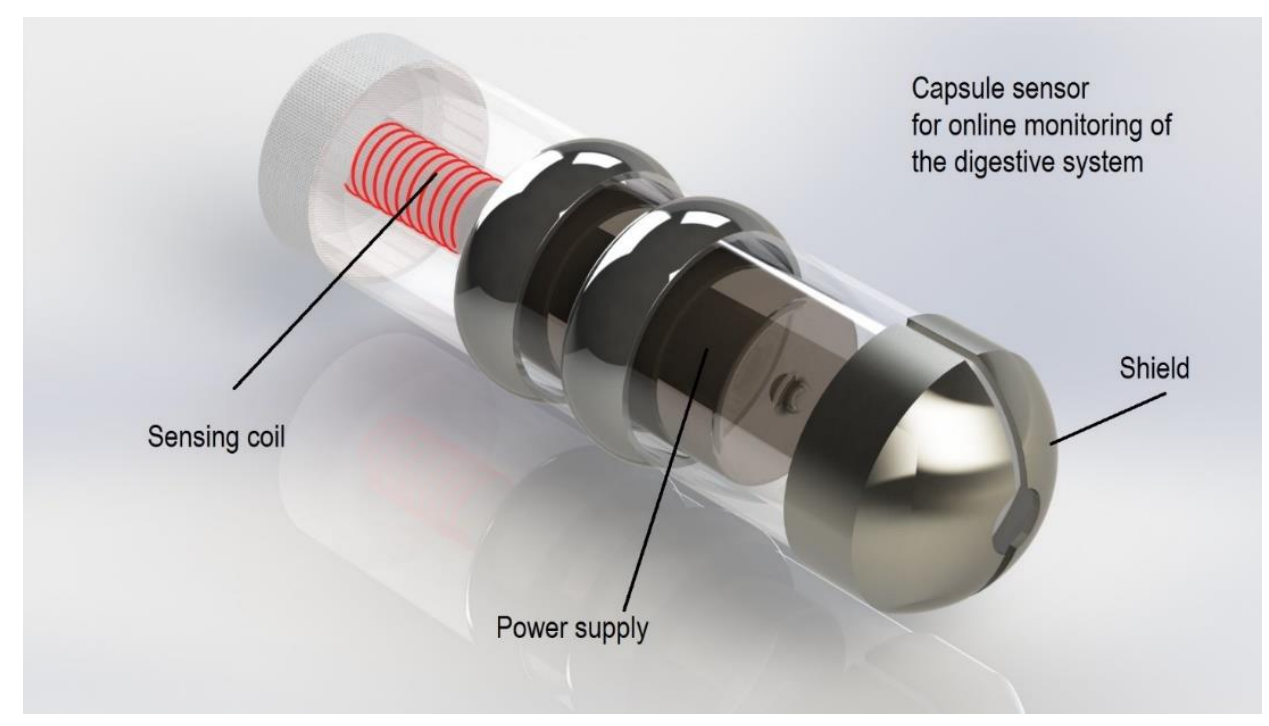

Рисунок 3, - на рисунке также показана модель интегрального сенсора, который вводится в осевое отверстие рукоятки ракетки для настольного тенниса.

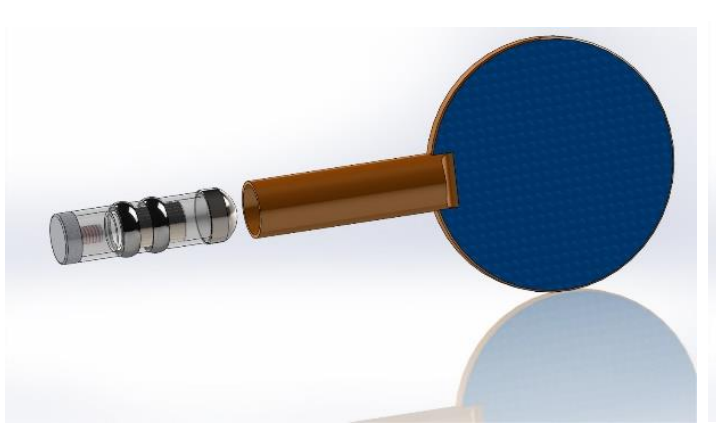

Рисунок 4

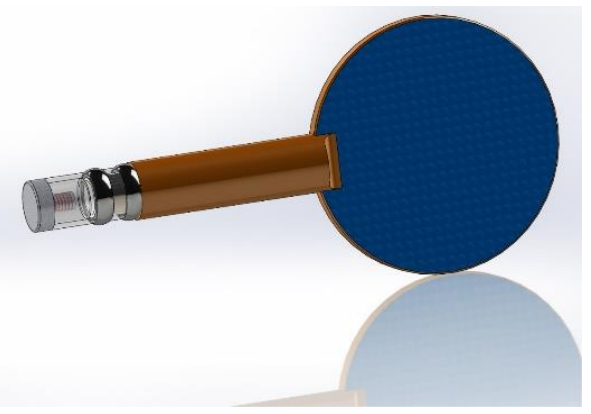

Рисунок 5 


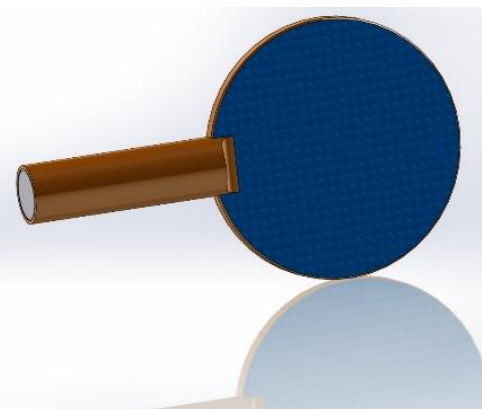

Рисунок 6

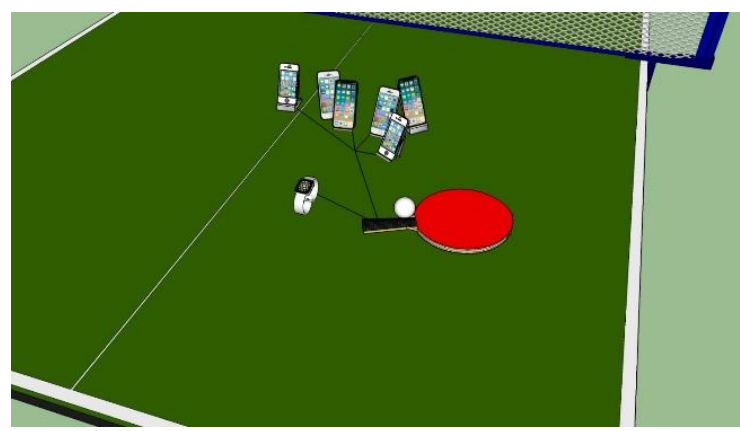

Рисунок 8

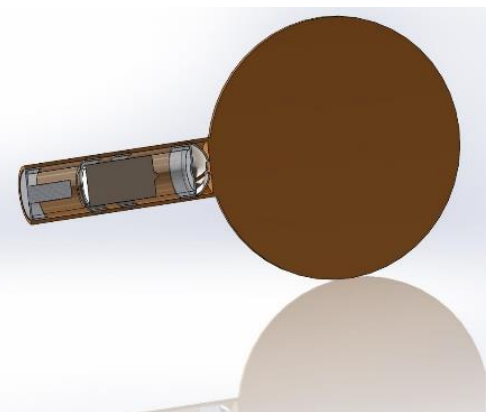

Рисунок 7

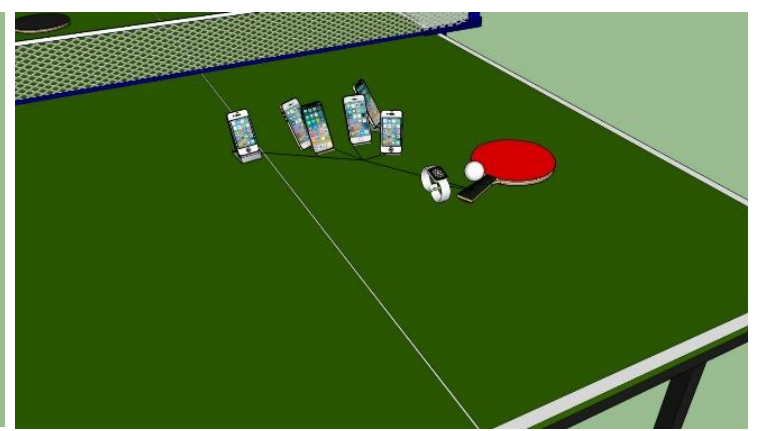

Рисунок 9

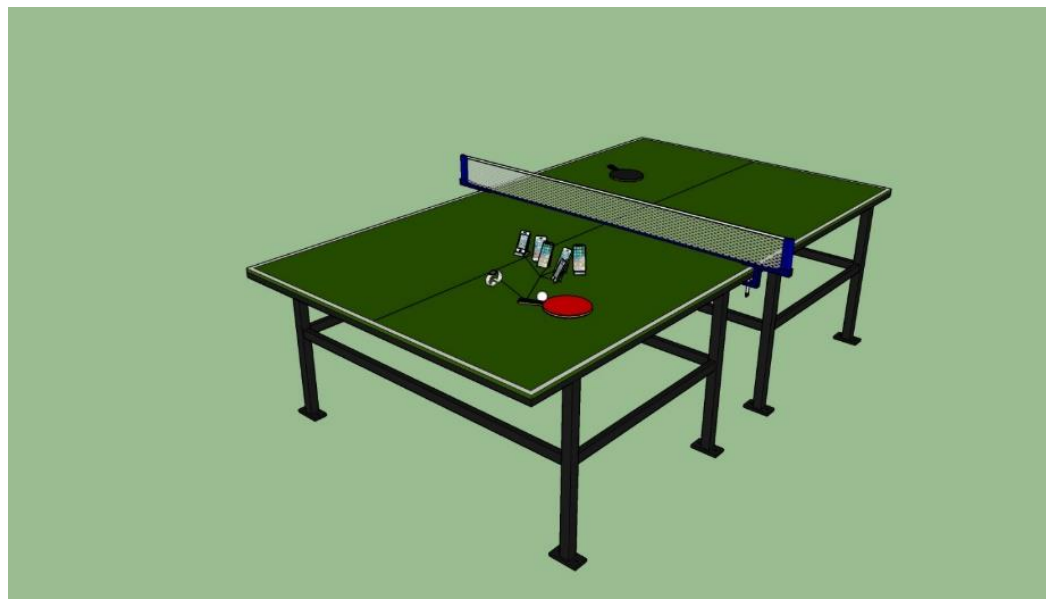

Рисунок 10

На рисунках 4-10 изображена модель.

Те, кто считают настольный теннис легким видом спорта, заблуждаются. Хотя, казалось бы, стоят два человека и перебрасывают друг другу мячик. Ну, что тут может быть сложного? Так думают лишь те, кто никогда не играл в настольный теннис. 
На самом деле «пинг-понг», развивает много не только физических, но и моральноволевых качеств. Это и сила, и ловкость, и быстрота реакции, и умение предсказывать, предвидеть ситуацию за игровым столом. При игре в теннис также развивается и мелкая моторика. Но рассмотрим все по порядку.

В таком виде спорта, как настольный теннис, сила развивается не в прямом понимании этого слова. Конечно, при занятии теннисом мышцы рук не будут такими, как у спортсменов бодибилдеров. Но мышцы, без сомнения, становятся рельефнее, так как работает плечевой сустав, бицепсы и трицепсы, а также мышцы кистей рук.

Здесь под силой подразумевается сила движения руки. Когда возникает необходимость резко атаковать соперника, застать его врасплох за столом, то удары по мячу должны быть мощными и сильными, то есть такими, чтобы соперник не сумел на них вовремя среагировать. Добавим к этому работу мышц ног, которые постоянно находятся в движении и напряжении.

Что же касается ловкости и быстроты реакции, то настольный теннис отлично развивает эти качества. Ведь при хорошей игре мяч летит очень быстро, поэтому, чтобы не потерять очки, необходимо действовать со всей ловкостью и быстротой, на которую только способен игрок.

Обычно ситуация за столом развивается мгновенно, поэтому необходимо также иметь некоторые умения предчувствовать будущее. И, буквально за долю секунды предугадать действие соперника, опередить направление полета мяча и силу удара, разгадать план действий и обмануть, а значит - обыграть.

Очень большая нагрузка в данной игре ложится на ноги игроков. Ноги выполняют большую работу по перемещению спортсмена около стола, их работа является важным фактором в игре и при достижении желанной победы. Поэтому не удивительно, что мышцы ног теннисистов очень хорошо натренированы, а это может значительно улучшить показатели и в других видах спорта, например, в беге. А значит, настольный теннис можно включить в систему тренировок некоторых спортсменов из других видов спорта.

Конечно, огромный оздоровительный эффект настольный теннис приносит сердечно- сосудистой и дыхательной системам. Ведь, перемещаясь от одного края стола к 
другому, мышцы сердца получают нагрузку, сравнимую с бегом по пересеченной местности. И чем лучше сердце натренировано, тем меньше риск сердечных заболеваний.

Дыхательная система при интенсивной игре также может получить развитие и очень полезный эффект. Происходит постоянная вентиляция легких, улучшается и тренируется их работа.

Нельзя оставить без внимания и положительный эффект от занятий на зрительную систему человека. Особенно, этот вид спорта полезен тем, кто много времени проводит за компьютером. Глаза постоянно перенапрягаются и устают. При игре в теннис происходит тренировка глазных мышц, потому что глаза должны следить за быстрым движением шарика, а также успевать реагировать и, при этом, еще наблюдать за действиями оппонента.

Бесспорно, «пинг-понг» отлично влияет на координацию движений, ведь нужно успевать отбивать летящий мяч, а для этого без точных и скоординированных движений всего тела просто не обойтись.

Настольный теннис развивает не только личные, но и деловые качества в характере человека.

Настольный теннис также полезен для людей, у которых есть жалобы на сердечнососудистые и дыхательные системы. Оздоровительный эффект, оказывающий положительное влияние именно на эти системы организма, доказан в процессе проведения c рассматриваемой категорией пациентов уникальных уроков по моей авторской методике.

Рассмотрим в чем же смысл. В процессе игры, когда игрок перемещается от одного края стола к другому, на мышцы сердца осуществляется нагрузка, сравнимая с нагрузкой во время бега. Польза тренировки сердца заключается в следующем: чем лучше ты тренируешь сердечную мышцу, тем меньше риск заболеваний сердечно-сосудистой системы, в том числе наступления сердечных приступов. Данная проблема очень актуальна в текущих условиях, так как именно сердечно-сосудистые заболевания занимают первое место среди причин смертности населения.

Какую же пользу настольный теннис оказывает на дыхательную систему организма? Благодаря дыхательным движениям происходит постоянная вентиляция легких, показателем которой является минутный объем дыхания (МОД) - количество 
воздуха, проходящее через легкие за 1 минуту. В покое МОД равен 5-8 л, а при физической нагрузке увеличивается и достигает 150-180 л. Обычно в покое человек потребляет 200300 мл кислорода в минуту. Во время игры в теннис потребление кислорода возрастает до 2-3 л/мин. И это закономерно. Мышечная работа немыслима без увеличения газообмена, поскольку энергия черпается в процессе окисления органических веществ. Даже при небольших физических нагрузках изменения дыхания четко выражены. При легкой работе обмен газов возрастает в 2-3 раза, при тяжелой - в 20-30 раз. Не занимающийся спортом человек делает 14-18 дыханий в минуту. При игре в теннис этот показатель может составлять 30-40. При значительной физической нагрузке легочная вентиляция увеличивается, в результате чего возрастает проникновение кислорода в кровь. При этом из каждого литра вдыхаемого воздуха кислорода используется больше (4-6\%), чем в покое (3-4\%). При увеличении нагрузок возрастает и скорость кровотока. Так, в покое за 1 минуту через сердце проходит 4-5 л крови. А вот при игре в теннис оно способно перекачивать до 35 л крови в минуту. На циркуляцию крови большое влияние оказывает и частота сердечных сокращений (ЧСС). В покое ЧСС колеблется от 50 до 80 уд/мин, при нагрузке значительно возрастает. Так, у теннисистов при разминке ЧСС составляет 120140 уд/мин, после подачи с выходом к сетке и короткого розыгрыша очка - 150-170 уд/мин, после упражнения «восьмерка» на задней линии - 172-190 уд/мин. Приведенные примеры показывают, что нагрузка у теннисистов-спортсменов во время соревнований и тренировочных занятий довольно большая. Она сопровождается и высокими пульсовыми показателями.

Также уникальность настольного тенниса заключается в том, что улучшается и зрительная система человека. А это особенно актуально для тех, кто много времени проводит за компьютером, например, работники IT сферы. В следствие регулярной работы за компьютером, они постоянно перенапрягаются и устают. При использовании моей авторской методики игры в настольный теннис происходит тренировка глазных мышц. Рассмотрим процесс подробнее. В ходе игры глаза должны следить за быстрым движением шарика, а также реагировать и при этом еще наблюдать за действием оппонента. То есть, глазные мышцы должны быть сфокусированы на нескольких разных точках. И по моей авторской технологии для их тренировки, в ходе разминки, я 
демонстрирую такую уникальную фигуру касания мяча, в которой оппонент должен отбить мяч.

Положительное влияние настольный теннис оказывает и на бизнес, а точнее на бизнесменов и предпринимателей, которые регулярно находятся в ситуациях, когда принимать решение приходится практически молниеносно. Теннис - это очень быстрый спорт, ситуация может меняться буквально за доли секунды. Поэтому здесь нужно уметь принимать правильные решения, практически не раздумывая. У бизнесменов, имеющих такое хобби, как настольный теннис, есть определенные преимущества.

\title{
A List of References, Patent and Licensing Information
}

1

United States Patent

$10,065,068$

Wilson

September 4, 2018

Adjustable ankle rehabilitation apparatus

\begin{abstract}
Various embodiments provide an adjustable ankle rehabilitation device for rehabilitating torn ligaments associated with a sprained ankle. The rehabilitation device can include a planar platform secured to a shoe, and a balancing rail adjustably attached to the bottom of the platform and extending fore to aft. The balancing rail is configured to selectively place a desired amount of stress on the medial muscle or, alternatively, the lateral muscle by adjusting the balancing rail from side-to-side. The device can include adjustable fasteners to secure the balancing rail at a desired position adjacent the bottom of the platform.
\end{abstract}

United States Patent

$9,616,283$

Heineck, et al.

April 11, 2017

Therapeutic device

\section{Abstract}

A low stress therapeutic device is provided by utilizing foot plates and guide rails having operationally tracking surfaces of a low coefficient of friction supported by a platform. 
The device includes a rail stabilizer equipped with extending longitudinally recess or slot and a slideably mounted foot plate having upon its underside a longitudinal projection slideably retained within the rail recess. The therapeutic device may be designed to operate under relatively effortless strain at a low coefficient of friction. The therapeutic device is useful for knee replacement, stroke victims, ACL repair, and other therapeutic treatments requiring a nominal initiating effort of movement for rehabilitation. The device may be provided as a one or two footed device of a light weight particularly useful in a patient sitting or lying position. The foot plates may be appropriately equipped with longitudinally underside tracking guides reciprocating sliding within longitudinal slots provided by a tracking rail.

Wearable power assistive device for hand rehabilitation

\begin{abstract}
A wearable power assistive device for hand rehabilitation includes a hand brace having an external platform and an internal platform connected to and spaced inwardly from the external platform. Five finger assemblies are adjustably mounted on and extending from the distal end of the external platform. Each finger assembly includes a proximal follower assembly for a metacarpophalangeal joint. Five motors are used to actuate the five finger assemblies respectively. Each motor is mounted in close proximity to the external platform and has one end connected to the external platform and another end coupled to its proximal follower assembly by a ball joint in order to facilitate transfer of force and minimize mechanical stress on the other parts of the device.
\end{abstract}

4

United States Patent

Rasmussen

August 14, 2007

Variable resistance aquatic device and methods of using the same

\begin{abstract}
An aquatic device is usable in an aquatic environment for a variety of purposes, such as physical therapy, rehabilitation, and/or exercise. The aquatic device permits a person to simulate a walking or running gait cycle in the aquatic environment, reducing the stress/strain
\end{abstract}


associated with walking or running on the ground. An aquatic device includes a foot-receiving member rotationally coupled to a fin member. The fin member, when in an extended position, provides increased resistance as the person attempts to walk or run in the aquatic environment. During a walking or running gait, the fin member moves into a folded position, thus reducing the resistance of the water on the aquatic device. The aquatic device is adaptable and modifiable to have varying shapes, designs, sizes, resistance levels, and/or other aspects.

\title{
5
}

United States Patent

$6,056,613$

Pike

May 2, 2000

Multi-purpose floatation device for recreation, exercise, instruction and rehabilitation purposes

\begin{abstract}
A recently popular form of exercise and therapy, aquatic exercising devices present unique operating conditions to the body because of their use of water resistance and their buoyancy. By making proper use of water resistance, such devices can provide the body with excellent muscular and cardiovascular training, at the same time, the buoyancy offered by these devices eliminates the stress and injuries associated with the jarring impact of such landbased exercises as running and aerobics. It is also an object of the present invention to provide an aquatic exercise devise that is a singular unit. The inventor began attending a water aerobic class in 1995 for health reasons. Exercising in the water took most of the pain out of the movement, but the inventor found that she was still hurting herself. She sought to reach a truly weightless state in which to condition her body. She tried the various devices provided by the pool facility but none proved effective in granting her the non-impact workout she was determined to find. With a problem to solve the inventor experimented, altered and designed a new and improved floatation device that is uniquely different in its adaptability to numerous applications. A uniquely different floatation device this invention goes beyond the restrictive designs of prior art designed to address one or another aspect of aquatic safety, exercise, rehabilitation or recreation. This invention adapts to usage in a multitude of expressions from water yoga, a unique synergy of ancient eastern culture and modern day technology; to aqua aerobic exercises incorporating cardiovascular enhancement activities; rehabilitation of physical injury or illness; as well as addressing the basic aspects of water safety and learning how to swim. A floatation device for various exercises, instruction, rehabilitation, therapeutic and/or recreational purposes; this invention provides floatation support as no other product on the market because of its unique design and flexibility and the multiple number of ways in which it can be used. With this invention its possible to float supine, moving through various water yoga relaxation movements and stretches; ride it like a bicycle seat; sit on it like a swing; wrap it around the torso and clip it on for deep water workout and/or for those who are uncomfortable in water, but who must get in for health and/or rehabilitation purposes; hold it with hands; slip it under arms, front to back, or back to front; all to move through various exercises for health, rehabilitation and fun. The variation is used to provide superior floatation in a clip on
\end{abstract}


style. With this invention secured around the torso, up the chest and around the back of the neck, the wearer is provided with no-hands support. While wearing the invention the wearer can float forward to swim and learn strokes; tread water in an upright position; and/or float supine; all with complete range of motion of limbs and/or torso. This variation of the invention can be utilized in swimming instruction, pool safety, rehabilitation, recreation, instruction and general poolside safety.

6

United States Patent

Bigelow, et al.

December 19, 1995

Treadmill for use with a wheelchair

\begin{abstract}
An exercise device for the occupant of a wheelchair acting as a treadmill which may be used for cardiac stress testing, cardiac or stroke rehabilitation, fitness training, aerobic training or educational/physical games, with the device including a generally inclined ramp having parallel sides, a forward entrance portion, a movable dolly mounted on rails on the sides of the ramp, the dolly having a pair of laterally movable caster capture plates with openings to receive the front casters of a wheelchair and angular rods cooperating with the wheelchair drive wheels acting to adjust the lateral spacing of said plates, locking means for the dolly to retain it in its forward position, separate locking means for locking the dolly in its rearward position when a wheelchair has been moved onto the ramp into operative position, a pair of enlarged openings adjacent the rear edge of the ramp, and a pair of longitudinally movable rollers beneath the ramp and movable between a rear retracted position allowing the wheelchair drive wheels to be partially received in the openings and a forward position under the drive wheels to engage and lift the drive wheels so that the user can manually rotate the wheelchair drive wheels to rotate the rollers and provide signals to a control apparatus for the desired type of training, testing or rehabilitation.
\end{abstract}

7

United States Patent Application

20130261514

Kind Code

TSUI; Michael Kam Fai ; et al.

October 3, 2013

WEARABLE POWER ASSISTIVE DEVICE FOR HAND REHABILITATION

Abstract 
A wearable power assistive device for hand rehabilitation includes a hand brace having an external platform and an internal platform connected to and spaced inwardly from the external platform. Five finger assemblies are adjustably mounted on and extending from the distal end of the external platform. Each finger assembly includes a proximal follower assembly for a metacarpophalangeal joint. Five motors are used to actuate the five finger assemblies respectively. Each motor is mounted in close proximity to the external platform and has one end connected to the external platform and another end coupled to its proximal follower assembly by a ball joint in order to facilitate transfer of force and minimize mechanical stress on the other parts of the device.

8

United States Patent Application

20120329611

Kind Code

Bouchard; Marc ; et al.

December 27, 2012

Motorized Lower Body Rehabilitation Device and Method

\begin{abstract}
Disclosed is a motorized rehabilitation apparatus and method for disabled, impaired or injured individuals, which trains a proper gait, increases blood flow, relieves stress, and reconditions lower body muscles and joints. The device comprises a powered stationary bicycle having a seat, handle grips, and rotating foot pedals that receive motive input from an electric motor and user input. The device further includes a pair of thigh braces that are connected together between the user's thighs via a hingeable link and chain that controls and trains an individual's limbs through the pedal rotation. The disclosed method further combines the present bicycle device for rehabilitation in conjunction with visual stimuli in the way of a three dimensional television display that stimulates endorphins, relieves mental stress and allows the motive input from the bicycle and mild user input to exercise the limbs of a user without focusing on the rehabilitation activity.
\end{abstract}

9

United States Patent Application

20070093153

Kind Code

Rasmussen; Scott K.

April 26, 2007

Variable resistance aquatic device and methods of using the same

Abstract 
An aquatic device is usable in an aquatic environment for a variety of purposes, such as physical therapy, rehabilitation, and/or exercise. The aquatic device permits a person to simulate a walking or running gait cycle in the aquatic environment, reducing the stress/strain associated with walking or running on the ground. An aquatic device includes a foot-receiving member rotationally coupled to a fin member. The fin member, when in an extended position, provides increased resistance as the person attempts to walk or run in the aquatic environment. During a walking or running gait, the fin member moves into a folded position, thus reducing the resistance of the water on the aquatic device. The aquatic device is adaptable and modifiable to have varying shapes, designs, sizes, resistance levels, and/or other aspects.

10

United States Patent Application

20060211937

Kind Code

Eldridge; Robert

September 21, 2006

Garment to facilitate use of a portable monitor device

\begin{abstract}
A garment configured to hold a portable medical device, and more particularly to a modified upper garment to hold, secure and conceal a heart monitor while allowing easy and unobtrusive access to cardiac lead points on a patient. The garment has an exterior pocket for a monitor. It further has a plurality of openings to allow attachment of monitor leads on a patient without the need to remove the garment. The openings may also have closure means. The garment provides modesty, comfort, durability and an attractive appearance. The garment may be configured for use in all cardiac rehabilitation situations including exercise and stress testing. The entire garment is made of $\mathrm{x}$-ray transparent materials.
\end{abstract}

11

United States Patent Application

20060142680

Kind Code

Iarocci; Michael Anthony

June 29, 2006

Active assist for the ankle, knee and other human joints

\begin{abstract}
A human joint assist device that applies a torque at the joint to assist physiological exertion forces, that is the load carrying task of the joint and surrounding muscles, tendons, and
\end{abstract}


ligaments. The application of this device reduces the physiological exertion force requirement, and may be adjusted with respect to assist level, to suit the issue associated with joint motion and is useful for joint rehabilitation and sports activities. Among other things, this results in a reduction of physiological exertion force in a fashion that makes it easier to extend the levers (long bones) associated with extension against a given resistance. For example, standing from a squatted position with the assist of this device reduces the stress on physiological members associated with joint articulation.

12

United States Patent Application

20180001172

Kind Code

SUTTA; Peters ; et al.

January 4, 2018

STRUCTURE OF ACCESSORY ELEMENT FOR EQUIPMENT OF FLOORBALL TRAINING COURT AND USE OF IT FOR FORMATION OF FLOORBALL SIMULATOR

\begin{abstract}
The invention refers to the equipment of the training rink for floorball, manufacturing of exerciser structural element, applying concept of tennis racket stringing. Proposed design of subsidiary element for floorball rink arrangement characterised with that it is made as latticework formed by: two parallel end plates; several threaded rods as stiffening members; two elastic string structures disposed in two parallel planes, at that each of it presents one side of mentioned latticework and provided with: --holes for fastening threaded rods which assure rigidity and load bearing capacity of the subsidiary element frame structure; --holes for crisscross stringing in two parallel planes and string fastening at mentioned end plates independently one from another.
\end{abstract}

13

United States Patent Application

20160296815

Kind Code

Pindrik; Michael

October 13, 2016

More To Bouncing Ball

\begin{abstract}
Easy to assemble and disassemble gaming apparatus that allows a single player to play a game comparable to Tennis and/or Ping Pong in a limited space environment The proposed game apparatus also allows a single player to perfect his or her skill.
\end{abstract}


14

United States Patent Application

20070238561

Kind Code

A1

$\mathrm{Hu}$; Liang-Fa

October 11, 2007

Structure of toy tennis racket

\begin{abstract}
Structure of toy tennis racket, which mainly improves composition of hitting face of toy tennis racket; it stretches string that one side is adhesive across holes around head of tennis racket in horizontal and longitudinal to make network, so that one side of this network is adhesive face and another side is the hitting face; such combination makes hitting face of toy tennis racket that can produce rebound force owing to the flexible network, furthermore, such racket may provide best ventilation effect to reduce wind resistance, you can hit ball easily as if playing with real tennis racket.
\end{abstract}

